\title{
The Problem of Food Security in Russia
}

\author{
Battalova A.R. \\ Kundakchyan R.M.
}

Kazan Federal University, Institute of Management, Economics and Finance, Kazan, 420008, Russia

\section{Doi:10.5901/mjss.2015.v6n3p773}

\section{Abstract}

Food security is defined as the constant availability of enough food for an active, healthy life for all people. Food, its production, distribution, exchange and consumption are an important part of the functioning of the global economic system, occupy a special place in the priorities of world politics. In today's world, agriculture remains an important source of income, employment and foreign trade. Even in countries in which the share of agriculture in GDP is small, consider this sector of the economy is important and pay him much attention.

Keywords: Food security, food, food provision, farms, agriculture

\section{Introduction}

The concept of food security was first formulated in the mid 70-ies of XX century, in relation to the current world paradoxical situation when absolute overproduction of food was accompanied by his enormous shortfall in the number of developing Third World countries, widespread hunger and starvation of tens of thousands of people. The original English term «food security», first introduced into wide use in the World Food Conference in Rome in 1974, which was organized by Food and Agriculture Organization (FAO), is translated in two ways: on the one hand as food security, and on the other hand - as food provision.

Currently, under the food security is usually understood the provision of physical and economic access to safe, sufficient in quantity and quality of food needed for an active and healthy life for all individuals and social groups of the population of any country of the world.

\section{Food Security of Russia: The Global Aspect}

Earth's population now exceeds 7 billion people and every 12-14 years increased by 1 billion, so it could reach 10 billion people approximately by 2050. To be sure, such increase would not be possible and will not be possible without proper food provision. The main "areas of demographic increase" are Asia, Africa and Latin America, which are the developing Third World countries.

However, many of them having favorable climatic and socio-economic conditions act as exporters of food (grain, meat, fish and seafood, fruits, spices, etc.). The volume of the global market for agricultural products is growing rapidly. In the years 2001-2012 in current prices, it has increased by 10.7\% per year. The increase was about 3.4 times from 551 billion dollars to 1.857 trillion dollars ( $9 \%$ of world trade). But at the same time it should be noted, almost $2 / 3$ of the increase due to the increase in prices (on average about 4-5\% per year) and an increase in exchange differencies (2-3\% per year). In this case, the actual food products occupy no more than $60 \%$ of this market: 1,083 trillion dollars in 2012 the rest being industrial crops (including biofuels) and other agricultural raw materials [5].

Russian Federation was a net food importer all that period of time, taking in this area $4.5-5.2 \%$ of the world market with the following indicators, which are presented in Table 1. 
Table 1. Export and import of food in Russia for 2000-2012 years.

\begin{tabular}{|c|c|c|c|}
\hline Year & Food exports, \$ bln (\% of total exports) & Food imports, \$ bln (\% of total imports) & Balance, \$ bln. \\
\hline 2000 & $1,623(1,6 \%)$ & $7,384(21,8 \%)$ & $-5,761$ \\
\hline 2001 & $1,887(1,9 \%)$ & $9,205(22,0 \%)$ & $-7,318$ \\
\hline 2002 & $2,801(2,6 \%)$ & $10,380(22,5 \%)$ & $-7,579$ \\
\hline 2003 & $3,411(2,5 \%)$ & $12,043(21,0 \%)$ & $-8,632$ \\
\hline 2004 & $3,292(1,8 \%)$ & $13,854(18,3 \%)$ & $-10,562$ \\
\hline 2005 & $4,492(1,9 \%)$ & $17,430(17,7 \%)$ & $-12,938$ \\
\hline 2006 & $5,514(1,8 \%)$ & $21,640(15,7 \%)$ & $-16,126$ \\
\hline 2007 & $9,090(2,6 \%)$ & $27,626(13,8 \%)$ & $-18,536$ \\
\hline 2008 & $9,278(2,0 \%)$ & $35,189(13,2 \%)$ & $-25,911$ \\
\hline 2009 & $9,967(3,3 \%)$ & $30,015(17,9 \%)$ & $-20,048$ \\
\hline 2010 & $9,365(2,3 \%)$ & $36,482(15,9 \%)$ & $-27,117$ \\
\hline 2011 & $11,964(2,3 \%)$ & $42,476(13,9 \%)$ & $-30,512$ \\
\hline 2012 & $16,343(2,8 \%)$ & $40,139(11,9 \%)$ & $-23,796$ \\
\hline Total & & & $-214,836$ \\
\hline
\end{tabular}

Consequently, during the 2000-2012 years our country "ate away" almost \$215 bln. This amount cannot be called astronomical, but it is very significant - especially in comparison with the data of its own agricultural production in Russia, which are presented in Table 2 [1].

Table 2. Import production and own farm products in the Russian Federation for 2005-2012 years

\begin{tabular}{|c|c|c|c|}
\hline Year & Food imports, \$bln & Own farm production in Russian Federation, \$bln & Import ratio (\% in the domestic market) \\
\hline 2005 & 17,430 & 48,832 & $35,69(28,21)$ \\
\hline 2006 & 21,640 & 57,762 & $37,46(29,28)$ \\
\hline 2007 & 27,626 & 74,840 & $36,91(29,59)$ \\
\hline 2008 & 35,189 & 99,047 & $35,52(28,16)$ \\
\hline 2009 & 30,015 & 79,267 & $37,87(30,22)$ \\
\hline 2010 & 36,482 & 85,137 & $42,85(32,50)$ \\
\hline 2011 & 42,476 & 111,131 & $38,22(29,99)$ \\
\hline 2012 & 40,139 & 102,685 & $39,09(31,74)$ \\
\hline
\end{tabular}

However, imports of food not only stably occupy more than a quarter of the national consumer market, but also demonstrate the significant upside potential in the event of adverse changes in the world market conjuncture for the Russian economy. Thus, the result of the crisis of 2008-2009, during which significantly reduced hydrocarbon prices, was an increase in the share of food imports in 2009-2010, almost a third of the national consumer market. In general, at the end of 2012, Russia accounted for $7.41 \%$ of global imports and $3.02 \%$ of world exports of food with a population equal to $2 \%$ of the Earth's population [1].

All of the above figures indicate significant potential as agricultural production in our country, and on a completely unsatisfactory nature of its use in the current version of the dynamic model of provision of its food security, which can be indicated as the "oil for food".

\section{Food Security of Russia: The Comparative-Historical Aspect}

Over the past 100 years the agriculture of our country and its closely related forestry and fishing as the main guarantor of food security held in Russia very complex, contradictory, and perhaps the most dramatic period of its development. All this, of course, influenced the character reflecting this development statistics. The analysis of the data, their use in the socio-economic research, in particular, when assessing the level of food security, not only require the most careful scrutiny, but many large-scale calculations of the original and clarifications, their modifications and additions in relation to the planned goals and tasks practically formats.

The volume of gross output of agriculture in Russia as a whole for 100 years (1900-2000) increased by only 1.36 times, including in 1961-1985 years. - by 1.6 times (in 1991-2000 decreased by 39.7\%; in 2001-2012 years also decreased by $15.5 \%)$. In this case, the crop areas under crops for 100 elapsed years in Russia decreased by $38.6 \%$ 
(from 74.3 to $45.6 \mathrm{mln}$ ha), the calculated yield of grain increased by 2.1 times (respectively from 7.6 to $15.6 \mathrm{dt} / \mathrm{ha}$ ), and the gross grain harvest - by 1.25 times (from 52.3 to 65.5 million tons).

The number of livestock by $25 \%$ for this period, including decreased by $20 \%$ of cattle (with 35 million of heads in 1900 to 28.0 million of heads in 2000), by $30 \%$ - the number of cows (respectively from 18.7 to 13.1 million of heads) by as much as $68.5 \%$ (from 47.0 to 14.8 million) reduced the number of sheep and goats, the number of pigs increased by 1.6 times (from 11.3 up to 18 million of heads). The production of meat in a century in Russia increased by 1.5 times (from 2.6 to 4.6 million tons in slaughter weight), milk - by 1.7 times (from 18.8 to 31.9 million tons) and eggs - by 4.8 times (from 6.1 to 33.9 billion pieces).

Russia in the past century has lost the main thing - the peasantry. If the share of large farms in the early XX century in Russia accounted for more than $40 \%$ of the gross grain harvest and $50 \%$ of commodity grain, $90 \%$ private and $50 \%$ of the leased land, while the share of landed estates - only $12 \%$ of the gross grain harvest and $22 \%$ of marketable grain, at the end of the century, large farms in the form of collective and state farms have virtually disappeared from the domestic economy, and farmers, whose share in 2001 accounted for only 3.7\% of the total agricultural production and $2.0 \%$ of all cattle (at $11 \%$ of arable land against $51.5 \%$ of total production at $5.7 \%$ of arable land in private households) have not lived up to expectations [4].

The revival of agriculture in Russia - is, first of all, the revival of the peasantry as the most intelligent, the most adventurous and the most prudent master of the country organically combines all the properties of nature, morality, culture and society, the peasantry as a class that initiates, rather than allegedly destroying large economy, collective work and personal wit, which are taken together, form a reliable support of the lean, the most efficient and therefore the most sustainable production.

In Russia, there were more than $18.5 \mathrm{mln}$ of farms (in USSR - 242.5 thousand of collectives and more than 5 thousand of state farms), in Russia today recorded the likes of former farms in 2002, there were only 265.5 thousand of units (in 1992 - 182.8 thousand.), including real counterparts, defined in terms of reliability and efficiency of the organization and production and economic activity - only a few hundred in the whole country [6].

In all the years committed so-called market-based agrarian reforms in the country (1992-2002years) incremented, therefore, only 82.7 thousand of peasant farm enterprises. That is an agricultural component of our institutional changes over the last decade almost go around in a circle, and now need to catch up.

\section{Calculation of Products Provision of Russian Regions}

In the Doctrine of food security are critical to Russia lists of the products and the minimum level of their own production, in particular, it is referred to grain (95\%), sugar (80\%), vegetable oil (80\%), meat (85\%), milk (90\%), fish (80\%), potatoes $(95 \%)$, and edible salt (85\%). The calculation of products provision is based on the formula, the essence of which is summarized as follows:

$$
\begin{aligned}
& \mathrm{a}^{\mathrm{t}}=\frac{\left(\left(1-\mathrm{k}_{\text {corn }}^{\mathrm{t}}\right) * \mathrm{R}_{\text {corn }}{ }^{*} \frac{\mathrm{a}_{\text {bread }}}{\mathrm{K}}+\left(1-\mathrm{K}_{\text {potatoes }}^{\mathrm{t}}\right){ }^{*} \mathrm{R}_{\text {potatoes }}{ }^{\mathrm{t}} \mathrm{a}_{\text {potatoes }}+\left(1-\mathrm{K}_{\text {milk }}^{\mathrm{t}}\right) * \mathrm{R}_{\text {milk }}{ }^{\mathrm{t}} \mathrm{a}_{\text {milk }}\right) * 10^{3}}{\left(\mathrm{H}_{\text {bread }}{ }^{*} \mathrm{a}_{\text {bread s }}+\mathrm{H}_{\text {potatoes }}{ }^{*} \mathrm{a}_{\text {potatoes }}+\mathrm{H}_{\text {milk }}{ }^{*} \mathrm{a}_{\text {milk }}+\mathrm{H}_{\text {vegetables }}{ }^{*} \mathrm{a}_{\text {vegetables }}+\mathrm{H}_{\text {shell eggs }}{ }^{*} \mathrm{a}_{\text {shell eggs }}+\mathrm{H}_{\text {meat }}{ }^{*} \mathrm{a}_{\text {meat }}\right) * \mathrm{~N}^{\mathrm{t}}} * 100+ \\
& +\frac{\left(\left(1-\mathrm{k}_{\text {vegetables }}^{\mathrm{t}}\right) * \mathrm{R}_{\text {vegetables }}^{\mathrm{t}} * \mathrm{a}_{\text {vegetables }}+\left(1-\mathrm{k}_{\text {shell eggs }}^{\mathrm{t}}\right) * \mathrm{R}_{\text {shell eggs }}^{\mathrm{t}} * \mathrm{a}_{\text {shell eggs }}+\left(1-\mathrm{k}_{\text {meat }}^{\mathrm{t}}\right) * \mathrm{R}_{\text {meat }}^{\mathrm{t}} * \mathrm{a}_{\text {meat }}\right) * 10^{3}}{\left(\mathrm{H}_{\text {bread }} * \mathrm{a}_{\text {bread }}+\mathrm{H}_{\text {potatoes }} * \mathrm{a}_{\text {potatoes }}+\mathrm{H}_{\text {milk }} * \mathrm{a}_{\text {milk }}+\mathrm{H}_{\text {vegetables }} * \mathrm{a}_{\text {vegetables }}+\mathrm{H}_{\text {shell eggs }} * \mathrm{a}_{\text {shell eggs }}+\mathrm{H}_{\text {meat }} * \mathrm{a}_{\text {meat }}\right) * \mathrm{~N}^{\mathrm{t}}} * 100 \%(1),
\end{aligned}
$$

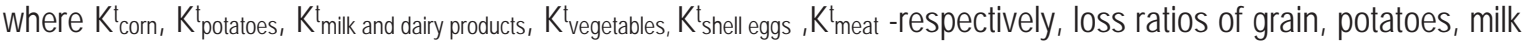
and dairy products, vegetables, shell eggs and meat during storage and processing, relative unit (an average taken $\mathrm{K}_{\text {corn }}^{\mathrm{t}}=0,2 ; \mathrm{K}_{\text {potatoes }}^{\mathrm{t}}=0,5 ; \mathrm{K}_{\text {milk and dairy products }}^{\mathrm{t}}=0,1 ; \mathrm{K}^{\mathrm{t}}$ vegetables $=0,5 ; \mathrm{K}^{\mathrm{t}}$ shell eggs $\left.=0,05 ; \mathrm{K}_{\text {meat }}^{\mathrm{t}}=0,2\right)$;

$R_{c o r n}^{t}, R_{\text {potatoes, }}^{t} R_{\text {milk and dairy products, }}^{t} R_{\text {vegetables, }} R_{\text {shell eggs }}^{t}, R_{\text {meat }}^{t}$ - respectively, sizes of own production of grain, potatoes, milk and dairy products, vegetables, shell eggs and meat are thousand tons (for eggs - million pieces);

$\mathrm{K}$ - average conversion factor produced grain in bread and bakery products $(K=1,33)$.

$\mathrm{H}$ corn, $\mathrm{H}$ potatoes, $\mathrm{H}$ milk and dairy products, $\mathrm{H}$ vegetables, $\mathrm{H}$ shell eggs, $\mathrm{H}$ meat - respectively, established by medical standards supply per capita consumption of bread and cereal products, potatoes, milk and dairy products, vegetables, shell eggs and meat, $\mathrm{kg} /$ year (for eggs - pieces / year);

a corn, a potatoes, a milk and dairy products, $\mathrm{a}$ vegetables, $\mathrm{a}$ shell eggs , a meat - respectively, average conversion factors are consumed by the population of bread and cereal products, potatoes, milk and dairy products, vegetables, shell eggs and meat, kcal / kg (for eggs - kcal / piece) [3].

For all these products the minimum level of own production is reached or nearly reached. The only point of doctrine, according to which food security is not assured - these are milk and dairy products. Russian production covers 
$80 \%$ of the demand, while the plan needs to cover $90 \%$.

\section{Conclusions}

In solving the problem of providing the population with food one of the factors of agricultural output from the financial crisis is the reform of the crediting system. Despite the fact that the Russian government has taken a number of measures to partially solve of this difficult problem, to solve it fully have not been able to. The main way to solve it is the provision of public investment credits. Instruments for the implementation of public investment are federal programs and the system of competitions. In this regard, a great role belongs to the mechanism of allocation of public investment resources provided as non-repayable and repayable [7]. Food Security of Russia is, ultimately, food provision and balanced nutrition of its population. Review of the problem of food security of Russia in the context of the overall Russian economic security is the topic of the hour, because it concentrated nodal direction of agrarian policy and economic reform in the new conditions of market relations. This process reflects the real trends in the development of agricultural production. Market conditions and the position of consumers on it, determined by the degree of involvement and dependence on the world food market, uses a mechanism of state strategy taking into account internal and external factors in order to create a critical life-support systems - food security [2].

The food problem in the near future will remain a priority in Russia's economic program. Alleviating of shortages and food availability will not only reduce social and ethnic instability in society, but also, no doubt, will help with the solution of a number of important issues of national security and socio-economic development. In turn, food security and food production growth will strengthen food independence of Russia, and their warranty - a guaranty of authority of the State on the international stage.

\section{References}

Russian statistical Yearbook. 2010: The statistical compilation / Rosstat. - M., 2012 - 813 p.

Battalova A.R., Abdullin I.A. Socioeconomic Processes in the Cis Countries // Mediterranean Journal of Social Sciences, Vol. 5, No. 24, (2014)

Kundakchyan R.M., Garifova L.F. Integral Estimate of Socio-Ecological-Economic Factors on the Quality of Life of Population of the Region / Kundakchyan R.M., Garifova L.F. // Mediterranean Journal of Social Sciences. Vol. 5, № 12 (2014).

6.Garifova L.F., Kundakchyan R.M. Pratchenko O.V. Integrated assessment of the impact of socio-ecological-economic factors on the quality of life of the population of the region / Mediterranean Journal of Social Sciences, vol 5, June 2014, p.117-121.

Safiullin L.N., Ismagilova G.N., Safiullin N.Z., Bagautdinova N.G. The de-velopment of welfare theory in conditions of changes in the quality of goods and services (2012) World Applied Sciences Journal 18 (Special Issue of Economics), pp. 144-149.

Gafurov, I.R., Platonova, O.U., Pratchenko, O.V. New state economic policy - Cluster policy cluster policy as the factor of innovative development of Europe. Mediterranean Journal of Social Sciences, 5 (12), pp. 107-111.

Valitov, S.M., Sirazetdinova, A.Z. (2014). Project risks' management model on an industrial entreprise. Asian Social Science, 10 (21), pp. 242-249.

Kirshin I.A. Modeling the long-term trend of accumulation of knowledge. Life Science Journal 2014; 11(6s): 482 - 486.

Melnik, A.N.,Dyrdonova, A.N. (2014). Infrastructural support for development of the territorial petrochemical cluster. Mediterranean Journal of Social Sciences, 5 (18 SPEC. ISSUE), pp. 299-304 